\title{
Upaya Meningkatkan Minta Baca Siswa Sekolah Dasar
}

\author{
Magdalena Elendiana \\ Program Studi Pendidikan Guru Sekolah Dasar \\ Fakultas Keguruan dan Ilmu Pendidikan \\ Universitas Kristen Satya Wacana, Indonesia \\ Email: Magdalenaelendiana25@gmail.com
}

\begin{abstract}
Abstrak
Penelitian ini bertujuan untuk mencari alternatif upaya meningkatkan minat baca siswa khususnya dikalangan sekolah dasar. minat baca merupakan suatu pengaruh yang besar bagi siswa . Upaya meningkatkan minat baca siswa sekolah dasar menjadi tanggung jawab bersama, antara siswa itu sendiri, guru maupun orang tua. Namun rendahnya minat baca siswa di sekolah dasar menjadi salah satu halangan, kurangnya keinginan dan kemauan dari siswa itu sendiri, guru juga belum mengharuskan siswa untuk membaca buku saat pembelajarn yang diajarkan kepada siswa. Dalam upaya meningkatkan minat baca siswa sekolah dasar sebaiknya siswa diberi dukungan agar minat baca itu muncul dari diri siswa dan dikenalkan dengan bahan bacaan supaya siswa tersebut terbiasa membaca, maka dari itu kebiasaan membaca siswa dimasa duduk di bangku sekolah dasar akan menumbuhkan minat baca yang tinggi hingga siswa tumbuh dewasa. Penelitian ini dilakukan dengan merumuskan masalah penelitian mencari refrensi-refrensi dari jurnal-jurnal yang relevan dan yang sejenis untuk dianalisis datanya, jurnal dikumpulkan dengan dengan menelusuri internet melalui Google Chendikia dan/atau Google Scholar. Data-data yang didapat dianalisis dan dibandingkan metode penelitian ini menggunakan Jenis penelitian deskriktif dengan pendekatan kuantitatif. Dari hasil analisis dapat meningkatkan minat baca siswa sekolah dasar.
\end{abstract}

Kata Kunci: Minat baca, siswa sekolah dasar.

\begin{abstract}
This research is aimed at finding alternatives to increase students special interest in reading among elementary schools. Interest in reading is of great importance to students. Efforts to increase reading interest in primary school student become a shared responsibility, between the students themselves, the teacher or parents. However, the low interest in reading students in primary schools iis one of the obstacles, less like and willingness of the students themselves, the teacher also does not need students to read books when they spend to spend for students. Students who are intested in reading at school. Students who support reading in school. Students who are interested in reading at school. Students grow up. This research problems looking for refrences from relevant and related journals for data analysis, journals collected using the internet through Google Chendikia and / or Google Scholar. The data obtained were analyzed and compared this research method using descriptive research with quantitative research. From the results of the analysis can increase reading interest in elementary school students.
\end{abstract}

Keywoards: Reading interest, elementary school students 


\section{PENDAHULUAN}

Minat baca merupakan suatu keinginan atau kecendrungan yang tinggi (gairah) untuk membaca (Siregar, 2004). Definisi itu sejalan dengan

pendapat Darmono yang menyatakan bahwa minat baca bahwa kecendrungan minat baca yang mendorong seseorang berbuat sesuatu terhadap membaca (Darmono, 2001; 182)

minat baca tumbuh dari diri siswa masing-masing sehingga untuk meningkatkan minat baca perlu kesadaran setiap individu. Membaca merupakan suatu keinginan dan kemauan untuk menuju kemajuan dan kesuksesan. Minat baca tersebut dapat diperoleh pada siswa duduk dibangku sekolah dasar, melalui kebiasaan membaca sejak duduk dibangku sekolah dasardengan banyaknya membaca maka siswa akan memiliki pengetahuan yang baru dan kemampuan membaca dengan alura pikiran yang telah siswa dapatkan dan minat baca dapat ditumbuhkan dan dikembangkan sehingga kebiasaan membaca dapat lebiih menambah pengetahuan luas. Dengan kegiata meningkatkan kegiatan membaca siswa sekolah dasar minat baca yang tinggi merupakan sesuatu yang diharapkan baik itu siswa sendiri, guru, maupun orang lain. Namun pada saat ini menumbuhkan minat baca pada siswa khusunya siswa sekolah dasar menjadi salah satu yang belum banyak dilaksanakan kurangnya keinginan,, kemauan dan dorongan dari diri sendiri siswa tersebut. dengan meningkatkan minat baca pada siswa dapat menambah pengetahuan dan makna yang terkandung dalam kata-kata, bahasa tertulis yang dibaca. Namun rendahnya minat baca siswa sekolah dasar menjadi halangan, kurangnya pembelajaran yang diajarkan dan guru belum mengharuskan siswa untuk membaca buku. Buku sebagai salah satu sumber pengetahuan baru melalui membaca, jadi minat baca siswa perlu dikembangkan lagi supaya siswa dapat memahami arti dalam bacaan yang dibaca. Melihat kenyataan tersebut, minat merupakan awal yang harus dipenuhi sebelum membaca. Sehingga jika dari awal sebelum membaca siswa dikenalkan dengan bahan bacaan dan

kebiasaan membaca, maka kebiasaan membaca dimasa duduk dibangku sekolah dasar akan menumbuhkan minat baca yang tingg hingga siswa

tersebut tumbuh dewasa.

Berdasarkan hasil penelitian- penelitian dalam dalam upaya meningkatkan minat baca siswa sekolah dasar belum banyak dilaksanakan yang dipengaruhi rendahnya minat baca siswa itu sendiri, Dari beberapa permasalahan tersebut, penulis akan melakukan tinjauan pustaka berdasarkan artiikel-artikel

relevan dengan topik yang akan dibahas dengan tujuan (1) Minat Baca Siswa Sekolah Dasar (2) Rendahnya Minat Baca dan (3) upaya meningkatkan minat baca siswa sekolah dasar.

\section{METODOLOGI PENELITIAN}

Penelitian ini dengan pendekatan kuantitatif. Penelitian kuantitatif dilakukan dengan menemukan data-data yang berbentuk tulisan.penelitian

ini mendeskripsikan sesuai dengan artikel- artikel yang bertujuan untuk menganalisis yang telah ketahui. Mengenai "Upaya Meningkatkan Minat Baca Siswa Sekolah Dasar" Dalam penelitian ini memperoleh Pengumpulan data dilakukan dengan menelusuri artikel yang ada dijurnal online Google Cendekia dan/atau Scholar. Dalam penelitian ini menggunakan triangulasi sumber data pengambilan data dengan cara mencari artikel-artikel dari beragam sumber.

\section{HASIL PENELITIAN DAN PEMBAHASAN}

\section{Minat}

\section{a. Pengertian Minat}

Minat adalah kecendrungan seseorang terhadap sesuatu atau bisa dikatakan apa yang disukai dan diinginkan oleh seseorang untuk dilakukan. Minat merupakan keinginan seseorang untuk 
melakukan sesuatu. Minat terhadap suatu yang dipengaruhi belajar selanjutnya serta

mempengaruhi keinginan, kemauan dan dorongan-dorongan. Jadi minat terhadap suatu merupakan hasil belajar dan menyokong hasil belajar selanjutnya. Asumsi umum menyatakan bahwa minat akan membantu seseorang yang mempelajari. Sedangkan menurut Ellis Ormarod (2008: 1001) minat presepsi bahwa suatu kegiataan menimbulkan rasa ingin tahu dan menarik biasanya disertai oleh keterlibatan kognitif dan efektif yang positif. Sedangkan menurut Crow and Crow dalam Abd. Rachman Aboro (1003: 112) minat berhubungan dengan daya gerak yang mendorong kita cenderung atau merasa tertarik pada orang, benda, giatan ataupun bisa pengalaman yang afektif yang dirasakan oleh kegiatan itu sendiri.

Menurut Guillfrod dalam Munardi (1996:146) minat adalah kecendrungan tingkah laku umum seseorang tertarik pada kelompok tertentu. Sementara itu, Tidjan, dkk 92008: 87) menjelaskan bahwa bila individu mempunyai minat maka akan mendorong individu untuk berbuat sesuatu.

\section{b. Pengertian Membaca}

Membaca merupakan suatu pemahaman isi dari apa yang tertulis dari buku. Membaca juga bertujuan untuk membentuk pemahaman oleh pembaca apa yang sedang di baca. Membaca juga memperoleh pengetahuan dan ilmu baru serta mendapatkan manfaat apa yang telah dipahami isi dari tulisan dan kata-kata yang terdapat dalam bacaan.

Menurut Puji Santoso (2009) berpendapat, membaca merupakan kegiatan memahami bahasa tulisan. Pesan dari sebuah teks atau barang cetak lainnya dapat diterima apabila pembaca dapat membacanya dengan tepat, akan tetapi terkadang pembaca juga salah dalam menerima pesan teks atau barang cetak manakala pembaca salah dalam membacanya.

Menurut Gondmen (1067:127) menyatakan bahwa membaca suatu kegiatan memetik makna atau pengertian yang bukan hanya dari deretan kata yang tersurat (reading the lines), melainkan makna di balik deretan yang diantara baris (reading between the lines). Aderson dalam Tarigan (2008:7) mengatakan, bahwa kegiatan membaca merupakan kegiatan mengubah tulisan atau cetakan menjadi bunyi-bunyi yang bermakna.

Dari beberapa pendapat para ahli membaca merupakan makna dari sebuah pesan tulisan memahami isi apa yang telah ditulis menggunakan kata-kata yang memetik makna dari bacaan-bacaan yang dibaca.

\section{a. Minat Membaca}

Minat membaca merupakan keinginan, kemauan dan dorongan dari diri sendiri siswa yang bersangkutan. Selain itu minat membaca merupakan minat yang mendorong kita supaya kita dapat merasakan ketertarikan dan senang terhadap aktivitas membaca dan mendapatkan pengetahuan yang luas dalam kegiatan membaca baik itu membaca buku supaya dapat memahami bahasa yang tertulis. Minat baca jura merupakan proses dari diri siswa sendiri. Minat baca perlu bimbingan supaya yang dapat membangun agar dapat tumbuh. Minat baca juga akan tumbuh bila ada kemauan, keinginan dan dorongan dari diri siswa sendiri, guru maupun orangtua. Rasa ingin tahu sesuatu dalam bentuk bacaan yang diminati setiap individu akan mendapat jawaban atas pertanyaan.

Menurut Tarigan

menyatakan minat baca merupakan kemampuan seseorang berkomunikasi 
dengan diri sendiri untuk menangkap makna yang terkandung dalam tulisan sehingga memberikan pengalaman emosi akibat dari bentuk perhatian yang mendalam terhadap makna baca. Minat membaca merupakan suatu perhatian yang kuat dan mendalam disertai dengan perasaan senang terhadap kegiatan membaca sehingga mengarahkan individu siswa untuk membaca dengan kemauan dan keinginan sendiri. Oleh karena itu sebagai seorang guru lebih menerapkan kegiatan membaca sebelum pembelajaran yang akan berlangsung minat baca kepada siswa sebagai keinginan yang kuat yang timbul dari diri siswa untuk mendapatkan pengetahuan yang baru dalam bentuk tulisan mendapatkan informasi yang terrkandung dalam bacaan yang dibaca.

\section{Rendahnya Minat Baca}

Rendahnya minat baca dapat berdampak buruk baik dari diri siswa sendiri maupun orang lain penyebab utama rendahnya minat baca siswa bisa jadi dari lingkungan keluarga dan dan lingkungan sekolah yang kurang mendukung aktivitas membaca. Rendahnya dukungan dari orang tua, guru ataupun teman-teman sebaya mengakibatkan siswa kurang minat membaca dan dampak negatif perkembangan dari siswa, dalam kegiatan pembelajaran belum mengharuskan siswa membaca. Seperti yang diungkapkan oleh Hardjoprakosa (2005:145) menyatakan bahwa yang menyebapkan rendahnya minat baca yaitu, para orang tua tidak memberi dorongan kepada anak untuk mengutamakan membeli buku dari pada mainan.

Peran sebagai seorang guru sangat mempengaruhi minat baca siswa (Haris dan Sipay, 1980). Hal tersebut tugas dari guru masih sangat kurang mendorong siswa untuk membaca.
Menurut Winarno (2012:37) mengenai permasalahan membaca tidak adanya teman yang memberikan semangat kepada temannya untuk membaca. Bahwa teman sebaya disekolah mempengaruhi minat baca siswa di sekolah dasar. Siswa bisa bosan karena dalam pembelajaran siswa hanya duduk dan diam tanpa adanya membaca terlebih dahulu sebelum pembelajaran ber;angsung.

3. Upaya Meningkatkan Minat Baca Siswa

Upaya meningkatkan minat baca perlu dibiasakan sejak awal pembelajaran supaya siswa dapat memahami makna dari isi teks tertulis yang telah dibaca. Membaca dapat dilakukan asalkan ada keinginan, kemauan dan dorongan dalam diri individu siswa sebagi seorang guru dan orang tua sebaiknya memberi dukungan. Bahwa kebiasaan membaca harus dimulai sejak awal tidak hanya disekolah menjadi

tempat menumbuhkan

minat membaca tetapi juga dirumah atau lingkungan yang dapat memberi hal yang positif bagi siswa dan dapat memanfaatkan buku- buku pembelajaran yang dapat meningkatkan minat baca siswa.

Menurut adzim (2004, hlm.52-67) beberapa hal yang dilakukan dalam upaya meningkatkan minat baca diantaranya: (a) orang tua menjadi figure membaca kepada anak (b) memilih bacaan yang sesuai pada dengan anak (c) buatlah saat membaca saat dengan anak)

Sedangkan menurut Astuti (2013. Hlm. 28) upaya meningkatkan dapat dilakukan sebagai berikut: (a) motivasi orang tua dan guru (b) promosikan gerakan gemar membaca di lingkungan sekolah. (c) memberikan penghargaan untuk anak yang gemar membaca (e) pengemasan buku yang menarik).

Minat baca tidak tumbuh begitu saja namun adanya usaha-usaha tertentu untuk 
membina minat baca tersebut menjadi lebih baik lagi. Demikian meningkatkan minat baca sisea berkaitan erat dengan kerangka tindakan AIDA (Attention, Interest, Desire dan Action) Rasa keingintahuan atau perhatian (attention) terhadap suatu objek (buku/teks) yang dibaca dapat menimbulkan rasa ketertarikan atau menaruh minat pada objek tersebut (Interest), rasa ketertarikan akan menimbulkan keinginan dan kemauan (desire) untuk membaca. Keiinginan yang tinggi pada diri siswa akan menimbulkan gairah untuk terus membaca (action) sehingga siswa selalu berusaha untuk memenuhi kebutuhanya yang dibaca dan mengerti makna dari katakata yang tertulis pada teks atau bacaan. Upaya yang dapat dilakukan untuk meningkatkan minat baca siswa diaantaranya: (a) perlu dukungan dari orang tua, guru dan teman-temannya (b) membiasakan siswa membaca buku sebelum pembelajaran berlangsung (c) memilih bacaan yang disukai siswa namun tetap mendidik (d) memberi pengaruh hal yang positif supaya siswa gemar membaca (e) memanfaatkan sarana dan prasarana yang ada.

\section{SIMPULAN}

Berdasarkan hasi penelitian dan pembahasan dapat disimpulkan bahwa upaya meningkatkan minat baca siswa sekolah dasar masih rendahnya minat baca sisw. Bagaimana upaya Meningkatkan minat baca menjadi tanggung jawab bersama baik dari pihak orang tua, guru, sekolah, teman-teman sebaya lingkungan sekitar.Siswa diberi dukungan agar minat baca muncul dari diri siswa itu sendiri. Hal tersebut minat baca sebaiknya lebih dikembangkan lagi supaya dalam kegiatan membaca siswa mendapatkan banyak manfaat membaca, mendapatkan pengetahuan yang baru dan mengetahui makna yang terkandung dalam isi dari teks bacaan yang dibaca.

Dalam lembaga pendidikan sebaiknya guru meningkatkan minat baca siswa, supaya dalam diri siswa ada juga keinginan dan kemauan.

\section{SARAN}

Berdasarkan simpulan hasil dari penelitian mengenai upaya meningkatkan minat baca siswa sekolah dasar. Penulis mengemukakan saran yang dapat dijadikan masukan bagi pihak sekolah hendaknya meningkatkan dengan menyediakan bukubuku yang menarik perhatian siswa dengan minat baca yang dimiliki siswa semakin meningkat. Bagi guru sebelum kegiatan pembelajaran berlangsung sebaiknya guru mengharuskan siswa untuk membaca. bagi pihak orang tua, hendaknya siswa tersebut diberi motivasi untuk meningkatkan minat baca bahwa membaca merupakan suatu kebutuhan. Bagi siswa hendaknya memiliki keinginan, kemauan dan dorongan dari diri siswa sendiri dengan membaca dapat menambah pengetahuan baru .

\section{DAFTAR PUSTAKA}

Ahmadi, F. (2010). Meningkatkan Minat\ Membaca Siswa Sekolah Dasar Dengan Metode Glenn Doman Berbasis Multimedia. Jurnal Penelitian Pendidikan, 27(1)

Aulawi, M. B. (2011). Optimalisasi layanan perpustakaan dalam meningkatkan minat baca siswa. Pustakaloka, 3(1), 117-127.

Daryanti, S., Widayat, W., \& Sulastiningsih, S. (2019). UPAYAMENINGKATKAN MINAT BACA SISWADENGAN MEMAKSIMALKAN PERAN SERTA WARGA SEKOLAH SEKOLAH DASAR I PATALAN, JETIS, BANTUL (Doctoral dissertation,

Wiwaha).

$$
\text { STIE Widya }
$$

Hasanah, M., Imran, I., \& Fatmawati, F. PERAN PENGELOLA RUMAH BACA

DALAM

AN

MENINGKATK MINAT BACA PADA

SISWA SEKOLAH

Proceedings, 2(2), 267-271. 
Kasiyun, S. (2015). Upaya meningkatkan minat baca sebagai sarana untuk mencerdaskan bangsa. Jurnal Pena Indonesia, 1(1),

Santoso, H. (2015). Upaya meningkatkan minat dan budaya membaca buku melalui iklan layanan masyarakat. Library. um. ac. id,(1), 1-19.

Siregar, A. R. (2008). Upaya meningkatkan minat baca di sekolah.

Parmadani, T. S., \& Latifah, L. (2016).

Pengaruh Minat Baca, Sumber Belajar Dan Lingkungan Teman Sebaya Terhadap Prestasi

Belajar Ekonomi.

Economic Education Analysis Journal, 5(2), 505-505.

Triatma, I. N. (2016). Minat baca pada siswa kelas VI sekolah dasar negeri delegan 2 prambanan sleman Yogyakarta. EJurnal Skripsi Program Studi Teknologi Pendidikan, 5(6), 166-178.

Sa'diyah, Z. (2015). Peningkatkan minat baca siswa di SDI Bani Hasyim Singosari Malang (Doctoral dissertation, Universitas Islam Negeri Maulana Malik Ibrahim).

Wahyuni, S. (2009). Menumbuhkembangkan minat baca menujumasyarakat literat. Diksi, 16(2).

Wulanjani, A. N., \& Anggraeni, C. W. (2019). Meningkatkan Minat Membaca melalui Gerakan Literasi Membaca bagi Siswa Sekolah Dasar. Proceeding of Biology Education, 3(1), 26-31. 